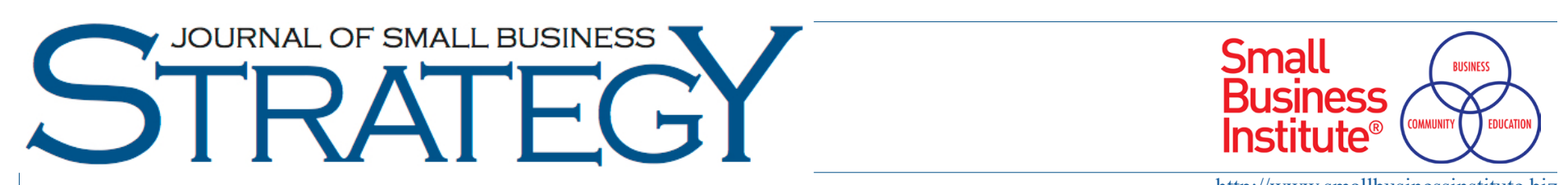

http://www.smallbusinessinstitute.biz

\title{
Strategic agility in the SME: Use it before you lose it
}

\author{
Jonathan Reed
}

Florida Institute of Technology, College of Business, 150 W University Blvd, Melbourne, FL 32901, USA, jreed2017@fit.edu

www.jsbs.org

Keywords:

Strategic agility, SME, Firm age, Firm size, Environmental turbulence

\section{A B S T R A C T}

This empirical study investigates strategic agility and its relationships with firm age, firm size, and firm performance in SMEs. The Doz and Kosonen three-factor model of strategic agility is operationalized and tested in 30 firms from multiple industries located in the Space Coast region of Florida. It is found that strategic agility decreases as firms grow older but not as firms grow larger. Strategic agility and firm performance are also found to be related as moderated by environmental turbulence. Specifically, performance increases with strategic agility in high turbulence but decreases with strategic agility in low turbulence. This finding is consistent with the view that dynamic capabilities like strategic agility bear a cost which may be unnecessary in stable environments. Overall, the study suggests that SMEs may benefit from strategic agility if it used while they still have it, that is, when they are young.

\section{Introduction}

Strategic agility is a relatively new construct in the field of strategic management which applies the notion of agility (flexibility and speed) to business strategy (Doz \& Kosonen, 2008a; Long, 2000). According to Doz and Kosonen (2008a; 2008b; 2010), strategically agile firms are able to change direction quickly through their heightened sensitivity to strategic developments (strategic sensitivity), making bold and fast decisions (leadership unity), and redeploying resources rapidly (resource fluidity). Strategic agility is therefore a type of dynamic capability, enabling firms to reconfigure their resources and capabilities to address rapidly changing environments (Teece et al., 2016; Teece et al., 1997).

Over the past decade, more than two dozen journal articles have been published on strategic agility, creating a vibrant research stream in strategic management. Much of the conceptual work builds upon Doz and Kosonen (2008a; 2008b). Weber and Tarba (2014), in their introduc-

Journal of Small Business Strategy

2021, Vol. 31, No. 03, 33-46

ISSN: 1081-8510 (Print) 2380-1751 (Online)

(C) Copyright 2021 Small Business Institute ${ }^{\circledR}$ tion to a special section of California Management Review on strategic agility, define it as "the ability of management to constantly and rapidly sense and respond to a changing environment by intentionally making strategic moves and consequently adapting the necessary organizational configuration for successful implementation" (p. 7). Other articles in the same publication discuss how strategic agility enables multinational enterprises to operate across emerging and established markets (Fourne et al., 2014), how different types of mergers and acquisitions enhance strategic agility (Brueller et al., 2014), and how leadership is central to managing the paradox between the long-term view of strategy and the short-term view of agility (Lewis et al., 2014). Vecchiato (2015) explores linkages between strategic foresight, first mover advantages, and strategic agility. Jacoby and Shaw (2016) use an athletics analogy to describe strategic agility in the U.S. military. They define strategic agility as the "capacity at the global or theater level to rapidly assess complex and unpredictable security challenges and opportunities and to decide and respond quickly, effectively, and efficiently" (p. 36). Kumkale (2016) argues that strategic agility is a tool for creating competitive advantage. Kwon et al. (2018) find strategic agility to be characteristic of successful Ko-

APA Citation Information: Reed, J. (2021). Strategic agility in the SME: Use it before you lose it. Journal of Small Business Strategy, 31(3), $33-46$. 
rean founders, and Ivory and Brooks (2018) find strategic agility to be involved in managing the paradox of corporate sustainability. Relevant to the present study, Arbussa et al. (2017) are interested in strategic agility in small firms. They conduct a longitudinal case study of a temporary workforce services company in Spain and find two of Doz and Kosonen's (2008a; 2008b) three dimensions present.

But is changing strategy good for the bottom line? On one hand, firms which are strategically agile may be able to outmaneuver their rivals in competitive environments, earning economic rents. On the other hand, changing strategy too often may lead to little market traction and unnecessary cost. Researchers have begun to empirically investigate the effect of strategic agility on firm performance, and the results so far appear mixed. Ojha (2008) finds a negative relationship between strategic agility and financial performance in medium-to-large sized U.S. manufacturing firms. Shin et al. (2015) find no relationship between strategic agility and financial performance in Korean manufacturers. Two very recent studies find positive relationships between strategic agility and firm performance in the Turkish accommodation industry (Kale et al., 2019) and German electronics firms (Clauss et al., 2019). Other researchers find interesting relationships between strategic agility and intellectual capital, competitive capabilities, and other constructs but not directly with firm performance (Al-Azzam et al., 2017; Junni et al., 2015; Khoshnood \& Nematizadeh, 2017; Ofoegbu \& Akanbi, 2012).

Assuming the different empirical findings are not explained methodologically, one might ask what contingency factors are involved in strategic agility. Unfortunately, little research has been conducted on the antecedents and moderators of strategic agility. This study addresses this gap by investigating the effects of firm age, firm size, and environmental turbulence on strategic agility and its relationship with firm performance. Small and medium-sized Enterprises (SMEs) were selected for the study as the SME and entrepreneurship literature suggest small and young firms are agile. The Space Coast region of Florida was selected as the context for the study due to its recent environmental turbulence. Multiple industries in this region were examined as the previous empirical studies were all single-industry based.

\section{Literature Review and Hypotheses}

The concept of agility in a business context has its roots in manufacturing. Researchers at the Iacocca Institute (Nagel, 1992; Nagel, \& Dove 1991) are most often cited as the first to use the term "agile manufacturing" in a study sponsored by the U.S. Office of Naval Research. They ar- gue that agility rather than mass production represented the future for $21^{\text {st }}$ century manufacturing (Gunasekaran, 2001). Over time, the concept extended from manufacturing into supply chain management (Dove, 1996; Yusuf et al., 2004) and information technology ( $\mathrm{Lu} \&$ Ramamurthy, 2011; Sambamurthy et al., 2003), where the ability to reconfigure the suppliers and systems underlying manufacturing would be beneficial.

\section{Strategic Agility}

The first use of the term "strategic agility" is found in Roth (1996) although it was still used in a manufacturing context. Roth defines strategic agility as "the capability to create the right products at the right place at the right time at the right price" (p. 30). Long (2000) is the first to address strategic agility in the strategic management sense. He defines strategic agility as "not only maintaining the flexibility to respond quickly to changing circumstances and emerging opportunities but also concentrating on a clear strategic purpose" (p. 38).

The concept of strategic agility is more thoroughly developed by Doz and Kosonen (2008a, 2008b, 2010). They propose that strategic agility is comprised of three dimensions: strategic sensitivity, leadership unity, and resource fluidity. Strategic sensitivity represents an intense awareness of external trends combined with an internally participative strategy process. It is proactive in nature, involving an open strategy process, heightened strategic alertness, and a future orientation. Leadership unity (also called collective commitment) allows the top management team to make bold decisions fast once a new strategic situation is perceived. It involves mutual dependency, collaboration, and an integrative leadership style on the part of the CEO. Resource fluidity is the internal capability to reconfigure capabilities and redeploy resources quickly once a new strategic direction is determined. It involves the alignment of strategy and structure, flexible business models, and modular systems and structures which can be reorganized quickly. According to Doz and Kosonen, all three dimensions are required for a firm to be strategically agile. "In short, the formulation is Agility = Sensitivity x Unity x Fluidity" (Doz \& Kosonen, 2008b, p. 111).

Doz and Kosonen (2010) provide a framework of five underlying determinants for each of the three dimensions. Each determinant is a type of leadership action that enhances strategic agility. Anticipating, for example, enhances strategic sensitivity by exploring concepts for how customers might use future products and services. Dialoguing enhances leadership unity by sharing strategic assumptions and hypotheses across the leadership team. Decoupling enhances 
resource fluidity by allowing organizational elements to operate in a coordinated but autonomous fashion. Hamalainen, Kosonen, and Doz (2012) illustrate the application of the framework to the public sector. Here, three antitheses of the strategic agility dimensions are identified: strategic atrophy, diverging commitments, and resource imprisonment. Most recently, Doz (2020) examines the framework from a human resources perspective. Firm age and firm size are both noted here as working against strategic agility. "Natural evolution leads to growing strategic rigidity as a company ages" and "achieving strategic sensitivity is even harder in the context of a large organization" (p. 3).

This study follows Doz and Kosonen (2008a; 2008b; 2010 ; 2020) by defining strategic agility as the firm's capability to dynamically change its plan for achieving sustained competitive advantage through its strategic sensitivity, leadership unity, and resource fluidity, by operationalizing their strategic agility framework, and by examining the effects of firm age and firm size more closely.

\section{Contingency Factors}

Turning to the contingency factors related to strategic agility, the entrepreneurship literature supports the relevance of firm age. Young firms, almost by definition, are entrepreneurial. Gunter (2012) defines entrepreneurs as "individuals who, in an uncertain environment, recognize opportunities that most fail to see, and create ventures to profit by exploiting these opportunities" (p 387). Kirzner (1997) defines entrepreneurial alertness as an attitude of receptiveness to available (but hitherto overlooked) opportunities. At the firm level, entrepreneurial orientation (autonomy, innovativeness, risk taking, proactiveness, and competitive aggressiveness) has been shown to be related to firm performance, particularly under conditions of environmental change (Covin \& Slevin, 1989; Lumpkin \& Dess, 1996). These concepts are similar to the strategic sensitivity dimension of strategic agility. Young firms, led by entrepreneurs with high entrepreneurial alertness and high entrepreneurial orientation, may be quicker to recognize and exploit new opportunities than older firms. These similarities between entrepreneurship and strategic agility suggest that younger firms may be more strategically agile than older firms. This leads to the first hypothesis.

Hypothesis 1. Firm age is related to strategic agility such that as SME firms become older, they become less strategically agile.

The SME literature suggests firm size is related to strategic agility. Small firms, due to their fewer resources and investments, are almost inherently flexible. Small firms are found to be better than larger firms at adjusting their production output (Fiegenbaum \& Karnani, 1991) and customizing their products (Ebben \& Johnson, 2005) to meet fluctuating market demand. Forbes (2005) finds small firms to be faster at making major decisions. Small firms are found to make greater use of informal versus formal plans (Allred et al., 2007). SMEs are less bureaucratic, enabling their managers to react quickly to new situations, stay closer to their customers, and adapt more rapidly to changing tastes (Garcia-Morales et al., 2007). These concepts are similar to the leadership unity and resource fluidity dimensions of strategic agility. From a theory perspective, SMEs are less path dependent (Arthur et al., 1987) and less constrained by the smaller asset stocks they have accumulated (Dierickx \& Cool, 1989). They may therefore be more flexible than larger firms anchored by their past decisions and capital investments. Given the flexibility of small firms and the similarities between flexibility and strategic agility, smaller firms may be more strategically agile than larger firms. This leads to the next hypothesis.

Hypothesis 2. Firm size is related to strategic agility such that as SME firms become larger, they become less strategically agile.

The relationship between strategic agility and firm performance is supported by the literature on dynamic capabilities. Dynamic capabilities lead to competitive advantage through the ability to acquire or reconfigure resources and competencies quickly, especially in rapidly changing environments (Eisenhardt \& Martin, 2000; Teece et al., 1997). Strategic agility is a type of dynamic capability in which the firm's strategy is the resource or competency dynamically changed. Teece (2009) describes dynamic capabilities in terms of sensing, seizing, and transforming, three components similar in nature to strategic agility's three dimensions. This leads to the third hypothesis.

Hypothesis 3. Strategic agility is related to firm performance such that as SME firms become more strategically agile, their performance improves.

However, strategic agility may not be as critical in stable environments as in conditions of environmental turbulence. Stable environments allow an existing strategy to be changed slowly or not at all if firm performance is deemed acceptable. Environmental turbulence challenges an existing strategy with environmental complexity, rapid change, novel challenges, and unpredictability (Ansoff et al., 1984/2019). Ansoff argues that strategic responsiveness 
must be matched to the level of environmental turbulence. Similarly, in the supply chain, stable environments place pressure on operational efficiency for enhanced competitiveness while unstable environments reward an agile supply chain (Yusuf et al., 2004). High environmental turbulence may therefore enhance the effect of strategic agility on firm performance. This leads to the fourth and final hypothesis.
Hypothesis 4. Environmental turbulence moderates the relationship between strategic agility and firm performance in SME firms.

Figure 1 summarizes the four hypotheses in the form of a conceptual model relating strategic agility, contingency factors, and firm performance.

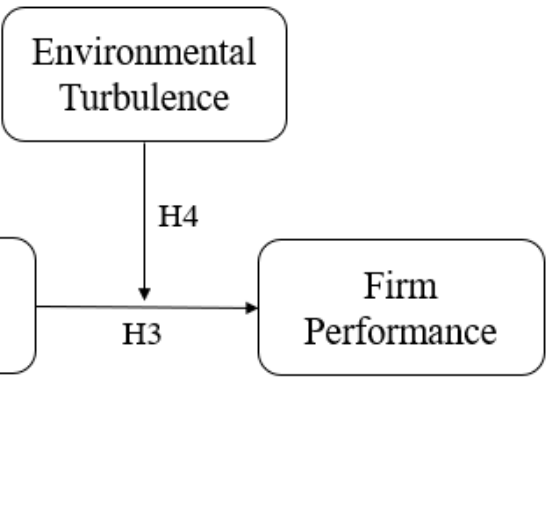

Figure 1. Hypothesized Relationships between Firm Age, Firm Size, Strategic Agility and Firm Performance

\section{Construct Validity}

As this is the first study to operationalize strategic agility following Doz and Kosonen (2010), it is important to assess the validity of the construct. One way of doing this is to compare strategic agility to like-constructs. Convergent validity is demonstrated when a construct is shown to correlate with a similar, established construct (Cooper \& Schindler, 2014). Organizational alignment was selected for this purpose. Organizational alignment is the degree to which an organization's strategy, structure, and culture cooperate to achieve the same desired goals (Nadler \& Tushman, 1989; Powell, 1992; Quiros, 2009; Semler, 1997). As this appears conceptually similar to strategic agility (the alignment of strategic sensitivity, leadership unity, and resource fluidity), a positive relationship between the two constructs would support convergent validity for strategic agility.

Criterion validity is demonstrated when a construct is shown to correlate with real-world outcomes (Sullivan et al., 2009). Strategy change was selected for this purpose. An organization may be strategically agile yet choose not to change its strategy during a given period of time. However, firms that are strategically agile may be expected to actually change their strategy more frequently. Strategy change is not a latent construct but rather a real-world event that may be measured objectively. A positive relationship between strategic agility and strategy change would therefore sup- port criterion validity for strategic agility. Note that organizational alignment and strategy change are not positioned as hypotheses as they are used for construct validation prior to hypothesis testing.

\section{Method}

\section{Context}

The Space Coast region of the State of Florida in the United States was selected as the context for the study. This region is on Florida's east coast and is comprised primarily of Brevard County, including the Palm Bay-MelbourneTitusville Metropolitan Statistical Area (MSA). One of the reasons this region was selected is its high industry diversity. According to Florida Gulf Coast University (2018), the Palm Bay-Melbourne-Titusville MSA ranked second in the state at the end of 2018 as an industrially diversified economy. High industry diversity is desirable for a multi-industry study. Another reason was that the region suffered economically from the combined effects of the national recession from 2007 to 2009 followed closely by the retirement of NASA's space shuttle program at the Kennedy Space Center from 2010 to 2011. Unemployment in Brevard County ran $1-3 \%$ higher than the national average from late 2009 to 2013, then rebounded and has been lower than the national average since early 2015 (Space Coast Economic 
Development Commission, 2018; 2019). These economic conditions represent a form of environmental turbulence suitable for the study.

According to the Dun \& Bradstreet (D\&B) Hoovers database, there are a total of 1,709 companies in six selected industry sectors in this region which are independent, for-profit, with 10 or more employees (D\&B Hoovers, 2018). From this population, stratified random sampling was used to generate a sample frame of 249 firms. A survey questionnaire was developed for data collection purposes and pretested and refined with seven firms from four industries. Questionnaires were sent by postal mail to the CEO of each firm and responses were accepted on-line or by return mail. 34 responses were received (13.7\% response rate), of which 30 were usable. The low response rate was likely due to the CEO level of the survey (Bednar \& Westphal, 2006) and the request for financial and other information which may be considered sensitive, especially for small firms (Dess \& Robinson, 1984). Table 1 summarizes the overall population, sample frame, and responses by firm size. While no responses were received from large firms (500 or more employees), the distribution of responses from very small to medium-sized firms was good, providing sufficient range in the sample to study the effects of firm size.

\section{Table 1}

Firm size distribution of population, sample frame, and responses

\begin{tabular}{lcccccccc}
\hline \multicolumn{1}{c}{ Firm Size } & $\begin{array}{c}\text { Number } \\
\text { Employees }\end{array}$ & $\begin{array}{c}\text { Pop. } \\
\text { Count }\end{array}$ & $\begin{array}{c}\text { Pop. } \\
\text { Percent }\end{array}$ & $\begin{array}{c}\text { Strat } \\
\text { Factor }\end{array}$ & $\begin{array}{c}\text { Sample } \\
\text { Frame } \\
\text { Count }\end{array}$ & $\begin{array}{c}\text { Sample } \\
\text { Frame } \\
\text { Percent }\end{array}$ & $\begin{array}{c}\text { Response } \\
\text { Count }\end{array}$ & $\begin{array}{c}\text { Response } \\
\text { Percent }\end{array}$ \\
\hline Large & $500+$ & 3 & $0.2 \%$ & $100 \%$ & 3 & $1.2 \%$ & 0 & $0.0 \%$ \\
Medium & $100-499$ & 59 & $3.5 \%$ & $100 \%$ & 59 & $23.7 \%$ & 7 & $23.3 \%$ \\
Small 2 & $50-99$ & 143 & $8.4 \%$ & $35 \%$ & 58 & $23.3 \%$ & 4 & $13.3 \%$ \\
Small 1 & $20-49$ & 518 & $30.3 \%$ & $10 \%$ & 67 & $26.9 \%$ & 8 & $26.7 \%$ \\
Very Small & $<20$ & 986 & $57.7 \%$ & $5 \%$ & 62 & $24.9 \%$ & 11 & $36.7 \%$ \\
\hline Total & & 1709 & $100 \%$ & & 249 & $100 \%$ & 30 & $100 \%$ \\
\hline
\end{tabular}

Table 2 summarizes the population, sample frame, and responses by industry sector. The construction and professional services sectors had the most responses while health/ social and accommodation/food had the fewest. Comparing the response percentages to the sample frame percentages indicates potential response bias by industry, suggesting the use of industry sector as a control variable relative to bias as well as traditional industry effects (Groves, 2006; Rumelt, 1991).

Table 2

Industry sector distribution of population, sample frame, and responses

\begin{tabular}{lccccccc}
\hline \multicolumn{1}{c}{ Industry Sector } & NAICS & $\begin{array}{c}\text { Pop. } \\
\text { Count }\end{array}$ & $\begin{array}{c}\text { Pop. } \\
\text { Percent }\end{array}$ & $\begin{array}{c}\text { Sample } \\
\text { Frame } \\
\text { Count }\end{array}$ & $\begin{array}{c}\text { Sample } \\
\text { Frame } \\
\text { Percent }\end{array}$ & $\begin{array}{c}\text { Response } \\
\text { Count** }\end{array}$ & $\begin{array}{c}\text { Response } \\
\text { Percent }\end{array}$ \\
\hline Construction & 23 & 314 & $18.4 \%$ & 45 & $18.1 \%$ & 8 & $26.7 \%$ \\
Manufacturing & $31,32,33$ & 196 & $11.5 \%$ & 38 & $15.3 \%$ & 5 & $16.7 \%$ \\
Retail Trade & 44,45 & 199 & $11.6 \%$ & 27 & $10.8 \%$ & 4 & $13.3 \%$ \\
Professional Services & 54 & 194 & $11.4 \%$ & 34 & $13.7 \%$ & 8 & $26.7 \%$ \\
Health/Social & 62 & 289 & $16.9 \%$ & 34 & $13.7 \%$ & 1 & $3.3 \%$ \\
Accomodation/Food & 72 & 517 & $30.3 \%$ & 71 & $28.5 \%$ & 2 & $6.7 \%$ \\
\hline Total & & 1709 & $100 \%$ & 249 & $100 \%$ & 28 & $100 \%$ \\
\hline
\end{tabular}

*Two responses did not report their industry 
The operationalization of each variable used in the study is discussed below.

\section{Firm Age}

The age of a firm is commonly measured as the number of years since its founding (Autio et al., 2000; U.S. Small Business Administration, 2012). For independent firms, founding is defined as the year of its legal incorporation. For branches or divisions of a larger firm, founding is defined as the year of the establishment of the outlet. The age of the firm was calculated as the current year minus the founding year.

\section{Firm Size}

Firm size may be measured in several ways including the number of employees, annual revenue, and assets. Number of employees was used in this study due to less sensitivity to its reporting by small, private firms. No distinction was made between full-time or part-time status.

\section{Strategic Agility}

A 10-item scale derived from Doz and Kosonen (2010) was used to measure strategic agility, and is provided in Appendix A. Each item was measured on a 7-point Likert-type scale ranging from Strongly Disagree (1) to Strongly Agree (7). The measures for each individual dimension were averaged to provide a composite value for the dimension. As Doz and Kosonen require all three dimensions to be present to achieve strategic agility, indicating an interaction between the dimensions, the three composite values were multiplied together to arrive at the final value for strategic agility. This value ranged from 1 to 343 .

\section{Environmental Turbulence}

"Environmental turbulence is a combined measure of the changeability and predictability of the firm's environment" (Ansoff et al., 1984/2019, p. 80). Four items derived from Ansoff et al. were used to measure environmental turbulence on a 5-point Likert-type scale ranging from Very Low (1) to Very High (5). These items measured the environment's complexity, novelty, speed of change, and frequency of shifts. The average of the items was calculated as the composite value for environmental turbulence. The scale is provided in Appendix A.

\section{Firm Performance}

Firm performance was measured as revenue growth, profitability, and subjective performance against objectives. Of these, profitability (return on sales) was found to be the most simple and reliable measure across firms of different ages, sizes, and industries, and was used as the dependent variable for the study. This is consistent with Powell's (1992) study of the relationship between organizational alignment and firm performance. Profitability was measured in ranges $(<0 \%, 0-5 \%, 5-10 \%, 10-15 \%, 15-20 \%, 20-25 \%$, > $25 \%)$ to reduce respondent concerns regarding the release of sensitive information.

\section{Organizational Alignment}

Organizational alignment was measured using four items derived from Semler (1997) to measure the pairwise consistency or fit between strategic goals, tactics, structure, cultural values and norms, and the external environment. The degree of alignment for each pair was measured on a 7-point Likert-type scale ranging from Strongly Disagree (1) to Strongly Agree (7). The average of the items was calculated as the composite value for organizational alignment. The scale is provided in Appendix A.

\section{Strategy Change}

Three original items were used to measure the degree to which a firm actually changed its strategy during the last three years. Using a 5-point scale, the items measured the frequency of strategy change (ranging from None to Continually), the degree of change (ranging from Very Minor to Very Major), and the speed of change (ranging from No Time At All to Years). The average of the three items was calculated as the composite value for strategy change.

\section{Industry}

Industry was measured as a nominal value corresponding to each industry sector. As a categorical variable, it then was encoded using dummy variables for the construction and professional services industries with higher response counts, and the remaining industries were grouped into a third "other" category, for use in regression analysis (Cohen et al., 2015).

\section{Analysis}

The two primary forms of analysis were factor analysis and multiple regression. Confirmatory Factor Analysis (CFA) was used to validate the ten survey items used 
to measure strategic agility. Factors were extracted using principal component analysis, as shown by Table 3 . The top three components, presumably corresponding to the three dimensions of strategic agility, met the rule-of-thumb criteria for Eigenvalues $>1.0$ and together accounted for $63.4 \%$ of the average variance explained. Table 4 provides the factor loadings of the survey items, showing clean loadings for most items on the components.

CFA and Cronbach's alpha were used to test the internal reliability of all five latent constructs in the study, as

Table 3

Principal component analysis for strategic agility

\begin{tabular}{|c|c|c|c|}
\hline \multirow[b]{2}{*}{ Component } & \multicolumn{3}{|c|}{ Initial Eigenvalues } \\
\hline & Total & Variance & $\%$ \\
\hline 1 & 3.336 & 33.364 & 33.364 \\
\hline 2 & 1.845 & 18.446 & 51.809 \\
\hline 3 & 1.164 & 11.635 & 63.445 \\
\hline 4 & 811 & 8.115 & 71.560 \\
\hline 5 & 695 & 6.954 & 78.513 \\
\hline 6 & 684 & 6.845 & 85.358 \\
\hline 7 & 609 & 6.094 & 91.452 \\
\hline 8 & 439 & 4.386 & 95.838 \\
\hline 9 & 291 & 2.905 & 98.744 \\
\hline 10 & 126 & 1.256 & 100.000 \\
\hline
\end{tabular}

Table 4

Loading of survey items on strategic agility components

\begin{tabular}{cccc}
\hline & \multicolumn{3}{c}{ Component } \\
Item & $\mathbf{1}$ & $\mathbf{2}$ & $\mathbf{3}$ \\
\hline SENSE1 & .529 & -.182 & $\mathbf{. 4 5 8}$ \\
SENSE2 & .161 & .395 & $\mathbf{. 7 8 9}$ \\
SENSE3 & .047 & .206 & $\mathbf{. 8 8 5}$ \\
UNITY1 &. $\mathbf{7 1 5}$ & -.145 & .202 \\
UNITY2 & $\mathbf{. 8 6 9}$ & .084 & .084 \\
UNITY3 &. $\mathbf{7 5 1}$ & .277 & -.154 \\
UNITY4 & $\mathbf{. 6 2 7}$ & .242 & .133 \\
FLUID1 & -.036 & $\mathbf{. 8 0 8}$ & .054 \\
FLUID2 & .059 & $\mathbf{. 6 9 9}$ & .241 \\
FLUID3 & .197 & $\mathbf{. 6 7 0}$ & .133 \\
\hline
\end{tabular}

Varimax rotation with Kaiser normalization summarized by Table 5. Strategic sensitivity and resource fluidity did not quite meet the rule-of-thumb minimum of .70 for coefficient alpha (Nunally, 1978). Strategic sensitivity also did not meet the rule-of-thumb minimum of .60 for one of its factor loadings. However, the Average Variance Explained (AVE) and Composite Reliability (CR) of the constructs did meet the rule-of-thumb minimums of .50 and .80 respectively (Fornell \& Larcker, 1981; Netemeyer et al., 2003).

Table 5

Reliability of latent variables

\begin{tabular}{lcccc}
\hline \multicolumn{1}{c}{ Construct } & $\begin{array}{c}\text { Cronbach's } \\
\text { Alpha }\end{array}$ & $\begin{array}{c}\text { Range of } \\
\text { Factor } \\
\text { Loadings* }\end{array}$ & $\begin{array}{c}\text { Average } \\
\text { Variance } \\
\text { Explained }\end{array}$ & $\begin{array}{c}\text { Composite } \\
\text { Reliability }\end{array}$ \\
\hline $\begin{array}{l}\text { Environmental } \\
\text { Turbulence }\end{array}$ & .766 & $.653-.852$ & .593 & .852 \\
$\begin{array}{l}\text { Organizational } \\
\text { Alignment }\end{array}$ & .769 & $.701-.847$ & .596 & .855 \\
$\begin{array}{l}\text { Strategic } \\
\text { Sensitivity }\end{array}$ & .695 & $.536-.894$ & .626 & .827 \\
$\begin{array}{l}\text { Leadership } \\
\text { Unity }\end{array}$ & .764 & $.667-.896$ & .587 & .849 \\
$\begin{array}{l}\text { Resource } \\
\text { Fluidity }\end{array}$ & .637 & $.751-.800$ & .592 & .813 \\
\hline *Unrotated & & & & \\
\end{tabular}

\section{Results and Discussion}

The means, standard deviations, and correlations are reported in Table 6. Firm age and firm size are positively correlated with one another, as would be expected. Firm age and strategic agility are negatively correlated, supporting H1. Firm size and strategic agility are not significantly correlated. Strategic agility is strongly positively correlated with both organizational alignment and strategy change $(p<.01)$, supporting the anticipated construct validity of strategic agility. None of the variables show a statistically significant correlation with firm performance.

The results of the regression analysis of strategic agility on firm age and firm size are shown in Table 7. Hierarchical regression was used to model industry control variables first, followed by the addition of firm age and firm size. Model 1 shows that industry alone accounts for $16.5 \%$ of the variance in strategic agility. Model 2 shows that firm age is still negatively related to strategic agility under industry control, adding $8.8 \%$ to the proportion of variance explained. Hypothesis 1 is therefore supported. Model 3 shows that firm size is not significantly related to strategic agility, providing no support for Hypothesis 2. Model 4 shows that the relationship between firm age and strategic agility is independent of firm size as well as industry. 
Table 6

Descriptive statistics and pearson correlations

\begin{tabular}{|c|c|c|c|c|c|c|c|c|c|c|}
\hline Variable & $\begin{array}{l}\text { Mean } \\
\text { (S.D.) }\end{array}$ & AGE & SIZE & AGILITY & TURB & PERF & ALIGN & CHANGE & CTRDUM & SRVDUM \\
\hline AGE & $\begin{array}{c}26.33 \\
(16.15)\end{array}$ & 1 & & & & & & & & \\
\hline SIZE & $\begin{array}{c}72.87 \\
(93.02)\end{array}$ & $.441 * *$ & 1 & & & & & & & \\
\hline AGILITY & $\begin{array}{r}136.80 \\
(58.30)\end{array}$ & $-.434 * *$ & -.042 & 1 & & & & & & \\
\hline TURB & $\begin{array}{c}3.37 \\
(0.60)\end{array}$ & -.092 & .061 & .253 & 1 & & & & & \\
\hline PERF & $\begin{array}{c}3.97 \\
(1.73)\end{array}$ & .050 & -.183 & .064 & -.123 & 1 & & & & \\
\hline ALIGN & $\begin{array}{c}5.58 \\
(0.84)\end{array}$ & $-.332^{*}$ & .066 & $.589 * * *$ & .255 & -.200 & 1 & & & \\
\hline CHANGE & $\begin{array}{c}2.34 \\
(0.85)\end{array}$ & $-.403 * *$ & .109 & $.486^{* * *}$ & $.334^{*}$ & -.047 & $.449 * *$ & 1 & & \\
\hline CTRDUM & $\begin{array}{c}0.27 \\
(0.45)\end{array}$ & $.315^{*}$ & .019 & $-.355^{*}$ & -.029 & -.210 & -.175 & $-.368 * *$ & 1 & \\
\hline SRVDUM & $\begin{array}{c}0.27 \\
(0.45)\end{array}$ & $-.359^{*}$ & -.064 & $-.313^{*}$ & .068 & .056 & .305 & -.038 & $-.364 * *$ & 1 \\
\hline
\end{tabular}

Table 7

Relationships of firm age and firm size with strategic agility

\begin{tabular}{|c|c|c|c|c|}
\hline \multirow[b]{2}{*}{$\begin{array}{l}\text { Independent } \\
\text { Vars }\end{array}$} & \multicolumn{4}{|c|}{ Dependent Var: AGILITY } \\
\hline & $\begin{array}{c}\text { Model } \\
1 \\
\text { Controls }\end{array}$ & $\begin{array}{c}\text { Model } \\
\mathbf{2} \\
\text { AGE }\end{array}$ & $\begin{array}{c}\text { Model } \\
3 \\
\text { SIZE }\end{array}$ & $\begin{array}{c}\text { Model } \\
4 \\
\text { AGE and } \\
\text { SIZE }\end{array}$ \\
\hline CTRDUM & -.278 & -.209 & -.248 & -.193 \\
\hline SRVDUM & .212 & .120 & .210 & .109 \\
\hline AGE & & $-.325^{*}$ & & $-.397 *$ \\
\hline SIZE & & & -.024 & .143 \\
\hline$R^{2}$ & .165 & .253 & .166 & .269 \\
\hline$\Delta R^{2}$ & & .088 & .001 & .016 \\
\hline Std. Error & 55.222 & 53.236 & 56.256 & 53.704 \\
\hline Sig. & .088 & .052 & .188 & .087 \\
\hline
\end{tabular}

Values are standardized coefficients

$* p<.10, * * p<.05, * * * p<.01$
The results of the regression analysis of firm performance on strategic agility and environmental turbulence are shown in Table 8. Model 1 shows that the industry controls account for only $4.4 \%$ of the variance in firm performance, and Model 2 shows that adding strategic agility has little effect. Hypothesis 3 was therefore not supported. Model 3 shows that adding environmental turbulence has little effect. However, Model 4 shows that the interaction between strategic agility and environmental turbulence is statistically significant and adds $10.5 \%$ to the proportion of variance explained. This supports Hypothesis 4.

Figure 2 graphically depicts the moderating effect of environmental turbulence. Under high turbulence (3.97), as strategic agility increases, so does firm performance. Under low turbulence (2.78), as strategic agility increases, performance actually decreases, suggesting that firms may be penalized for their strategic agility in stable environments. Probing the interaction (Hayes, 2018) at multiple levels of turbulence shows that the point at which the relationship between strategic agility and performance switches between positive and negative is approximately 3.4 on the 5-point turbulence scale ranging from Very Low (1) to Very High (5). 
Table 8

Relationships between strategic agility, environmental turbulence, and firm performance

\begin{tabular}{lcccc}
\hline \multicolumn{1}{c}{ Independent Vars } & $\begin{array}{c}\text { Dependent Var: AGILITY } \\
\text { Model 1 } \\
\text { Controls }\end{array}$ & $\begin{array}{c}\text { Model 2 } \\
\text { AGILTY }\end{array}$ & $\begin{array}{c}\text { Model 3 } \\
\text { TURB }\end{array}$ & $\begin{array}{c}\text { Model 4 } \\
\text { AGILTYxTURB }\end{array}$ \\
\hline CTRDUM & -.218 & -.220 & -.210 & -.229 \\
SRVDUM & -.023 & -.022 & -.021 & -.008 \\
AGILITY & & -.008 & .030 & -2.029 \\
TURB & & & -.135 & $-1.078^{*}$ \\
AGILITYxTURB & & & & $2.483^{*}$ \\
$\mathrm{R}^{2}$ & .044 & 044 & .061 & .167 \\
$\Delta \mathrm{R}^{2}$ & & .000 & .017 & .105 \\
Std. Error & 1.754 & 1.788 & 1.807 & 1.738 \\
Sig. & .542 & .752 & .800 & .462 \\
\hline
\end{tabular}

Values are standardized coefficients

$* p<.10, * * p<.05, * * * p<.01$

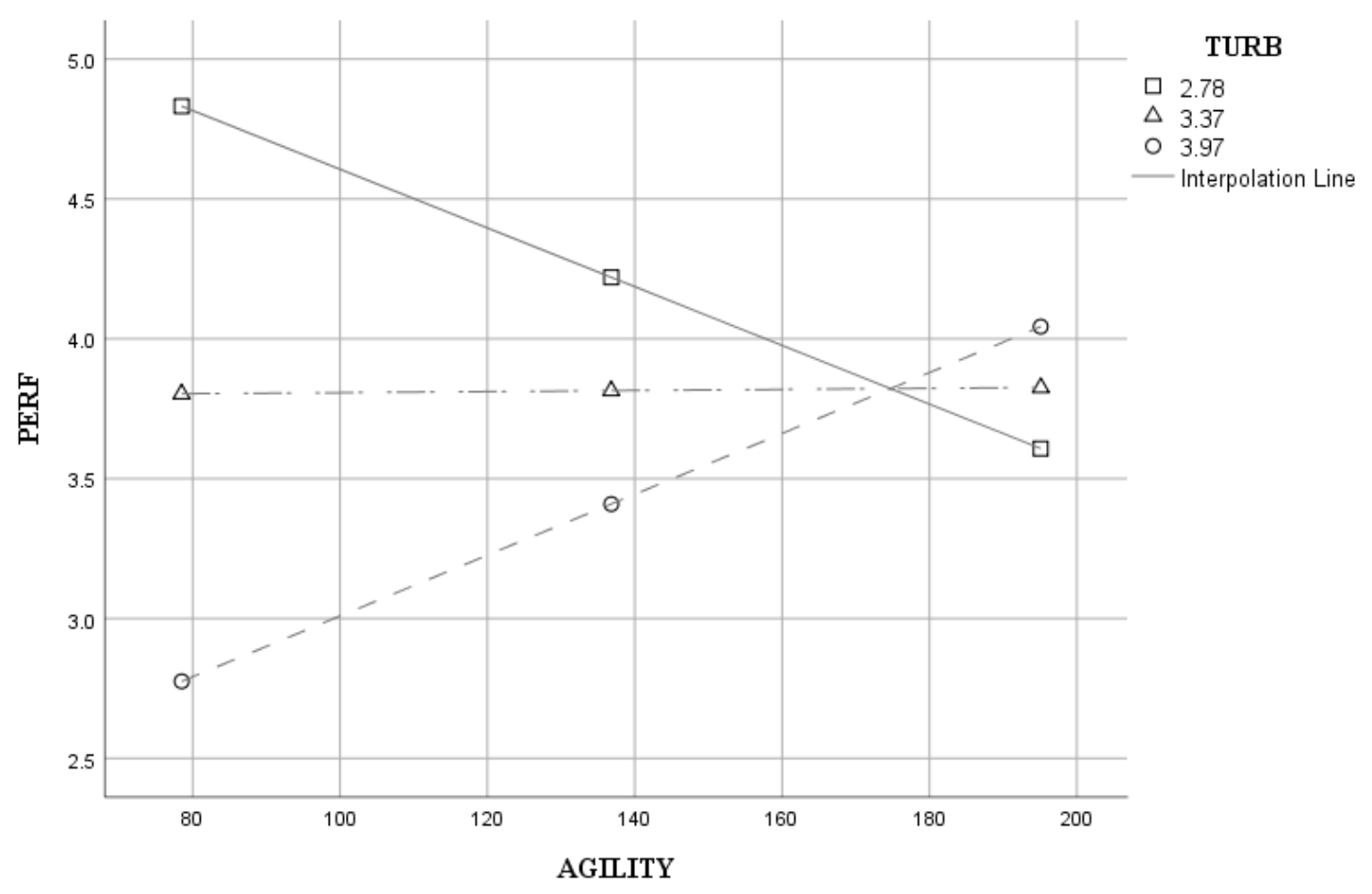

Figure 2. Plot of Moderating Effect of Environmental Turbulence

The performance penalty for strategic agility in stable environments is consistent with Winter's (2003) view that dynamic capabilities are not always warranted given their greater cost in comparison to ordinary capabilities (routines) and ad hoc problem solving. According to Winter, dynamic capabilities involve a carrying cost for the specialized resources which enable it to change lower-order capabilities. Firms without dynamic capabilities can still accomplish change through ad hoc problem solving, the costs of which generally disappear when there is no problem to solve. Therefore, when the need for change is sparse, the added cost of dynamic capabilities may not be matched by corresponding benefits.

In summary, the hypothesis that firm age is negatively related to strategic agility (H1) was supported by the study. As firms became older, they became less strategically agile. This is consistent with prior research in the areas of path dependency, asset stock accumulation, and structural inertia 
(Barney, 1991; Dierickx \& Cool, 1989; Hannan \& Freeman, 1984). The hypothesis that firm size is negatively related to strategic agility (H2) was not supported, despite the correlation found between firm age and size. While surprising, previous studies have also found the effects of firm age and firm size to be separate and independent (Esteve-Perez \& Manez-Castillejo, 2006; Freeman et al., 1983; Gopalakrishnan \& Bierly, 2006). The hypothesis that strategic agility was unconditionally related to firm performance (Hypothesis 3 ) was also not supported. However, the hypothesis that environmental turbulence positively moderates the relationship between strategic agility and performance (Hypothesis 4) was supported. As firms became more strategically agile, they performed better in turbulent environments and worse in stable environments. This negative impact in low turbulence might be called the "Winter effect" after Sidney Winter, who argued that dynamic capabilities are expected to carry additional costs that may be an unnecessary burden in low turbulence (Collis, 1994; Winter, 2003). This finding may also help explain the mixed results in prior research on the relationship between strategic agility and firm performance.

\section{Implications, Limitations, and Future Research}

This study contributes to theory in two ways. First, it operationalizes the Doz and Kosonen (2010) framework describing strategic agility and finds it to be valid both internally through CFA and externally through convergence with similar constructs. The resulting scale may prove useful to researchers investigating strategic agility and may lead to more consistent findings in the future. Second, two contingency factors related to strategic agility are identified. Firm age is found to be an antecedent of strategic agility, and environmental turbulence is found to be a moderator of the relationship between strategic agility and performance. These findings help to "build out" our conceptual understanding of the role of strategic agility.

The study also has two significant managerial implications. Young firms may be able to leverage strategic agility as a source of competitive advantage, particularly when competing against older firms. However, they should bear in mind that they may lose strategic agility as they grow older. That is, they should use it before they lose it. Firms may therefore wish to use the scale to monitor their strategic agility and to maintain it through exercise or develop it through training. Second, firms may enhance their performance by matching their level of strategic agility with the level of turbulence in their environment. High strategic agility appears to pay off in high turbulence, whereas low strategic agility appears to pay off in low turbulence.
This suggests that the ability to dynamically adjust strategic agility is a useful second-order dynamic capability (Winter, 2003).

There are several limitations in the study. The generalizability of the results is limited by the focus on firms located in a specific region of one state. The results may therefore not apply to other geographies which are markedly different in industry mix or environmental factors. The study is also limited by its small sample size. While statistically significant results are found, stronger relationships and results involving firm size may be found with a greater number of firms. Finally, the study is limited by the use of single-rater survey data as opposed to multiple, more objective sources of data. While the behavioral nature of strategic agility requires a questionnaire, some constructs such as firm performance and environmental turbulence might be collected from public filings or industry databases. Multiple raters for each firm might also be used to reduce bias and increase the sample size. Each of these limitations warrants additional research.

The study should also be expanded to include large firms. Large firms generally have greater resources, more products and services, larger market share, economies of scale, and other advantages over SME firms (Penrose, 1959). However, these advantages may become disadvantages when it comes to strategic agility. Large firms may not be able to shift their resources or market focus as easily or quickly as small firms. Grantham et al. (2007) argue that the agility of large corporations is limited by their real estate, human resources, and IT investments. While firm size was included in this study, it remains to be seen if the findings extend to firms with one thousand or ten thousand employees and revenues measured in billions.

Finally, the longitudinal study of strategic agility is recommended. By measuring and tracking the strategic agility of one or more firms over time, causal relationships may be identified in how the capability is developed, lost, and linked to outcomes. Unfortunately, unless archival data is used, it may take years for the longitudinal study of strategic agility to witness the results of strategic change.

\section{References}

Al-Azzam, Z. F., Irtaimeh, H. J., \& Khaddam, A. A. H. (2017). Examining the mediating effect of strategic agility in the relationship between intellectual capital and organizational excellence in Jordan service sector. Journal of Business, 6(1), 7-15.

Allred, A., Addams, H., \& Chakraborty, G. (2007). Is informal planning the key to the success of the Inc. 500? Journal of Small Business Strategy, 18(1), 95-104. 
Ansoff, H. I., Kipley, D., Lewis, A. O., Helm-Stevens, R., \& Ansoff, R. (2019). Implanting Strategic Management $\left(3^{\text {rd }}\right.$ ed). Palgrave MacMillan. (Original work published 1984)

Arbussa, A., Bikfalvi, A., \& Marques, P. (2017). Strategic agility-driven business model renewal: The case of an SME. Management Decision, 55(2), 271-293.

Arthur, W. B., Ermoliev, Y. M., \& Kaniovski, Y. M. (1987). Path-dependent processes and the emergence of macrostructure. European Journal of Operational Research, 30(3), 294-303.

Autio, E., Sapienza, H. J., \& Almeida, J. G. (2000). Effects of age at entry, knowledge intensity, and imitability on international growth. Academy of Management Journal, 43(5), 909-924.

Barney, J. B. (1991). Firm resources and sustained competitive advantage. Journal of Management, 17(1), 99120.

Bednar, M. K., \& Westphal, J. D. (2006). Surveying the corporate elite: Theoretical and practical guidance on improving response rates and response quality in top management survey questionnaires. Research Methodology in Strategy and Management, 3, 37-55.

Brueller, N. N., Carmeli, A., \& Drori, I. (2014). How do different types of mergers and acquisitions facilitate strategic agility? California Management Review, 56(3), 39-57.

Clauss, T., Abebe, M., Tangpong, C., \& Hock, M. (2019). Strategic agility, business model innovation, and firm performance: An empirical investigation. IEEE Transactions on Engineering Management (Early Access), 1-18. DOI 10.1109/TEM.2019.2910381

Cohen, J., Cohen, P., West, S. G., \& Aiken, L. S. (2015). Applied multiple regression/correlation analysis for the behavior sciences $\left(3^{\text {rd }}\right.$ ed.). Routledge.

Collis, D. J. (1994). Research note: How valuable are organizational capabilities? Strategic Management Journal, 15(S1), 143-152.

Cooper, D. R., \& Schindler, P. S. (2014). Business research methods. McGraw-Hill.

Covin, J. G., \& Slevin, D. P. (1989). Strategic management of small firms in hostile and benign environments. Strategic Management Journal, 10(1), 75-87.

D\&B Hoovers. (2018). D\&B Hoovers: Accelerate the path from prospect to profitable relationship. https://www. dnb.com/products/marketing-sales/dnb-hoovers.html

Dess, G. G., \& Robinson, R. B., Jr. (1984). Measuring organizational performance in the absence of objective measures: The case of the privately-held firm and conglomerate business unit. Strategic Management Journal, 5(3), 265-273.
Dierickx, I., \& Cool, K. (1989). Asset stock accumulation and sustainability of competitive advantage. Management Science, 35(12), 1504-1511.

Dove, R. (1996). Agile supply-chain management. Automotive Production, 108(4), 16-17.

Doz, Y. L., \& Kosonen, M. (2008a). Fast strategy: How strategic agility will help you stay ahead of the game. Wharton School Publishing.

Doz, Y. L., \& Kosonen, M. (2008b). The dynamics of strategic agility: Nokia's rollercoaster experience. California Management Review, 50(3), 95-118.

Doz, Y. L., \& Kosonen, M. (2010). Embedding strategic agility: A leadership agenda for accelerating business model renewal. Long Range Planning, 43(2-3), 370382.

Doz, Y. (2020). Fostering strategic agility: How individual executives and human resource practices contribute. Human Resource Management Review, 30(1), 1-14.

Ebben, J., \& Johnson, A. (2005). Efficiency, flexibility, or both? Evidence linking strategy to performance in small firms. Strategic Management Journal, 26(13), 1249-1259.

Eisenhardt, K., \& Martin, J. (2000). Dynamic capabilities: What are they? Strategic Management Journal, 21(1011), 1105-1121.

Esteve-Perez, S., \& Manez-Castillejo, J. A. (2006). The resource-based theory of the firm and firm survival. Small Business Economics, 30(3), 231-249.

Fiegenbaum, A., \& Karnani, A. (1991). Output flexibility - a competitive advantage for small firms. Strategic Management Journal, 12(2), 101-114.

Florida Gulf Coast University. (2019). FGCU industry diversification index, $4^{\text {th }}$ Quarter 2018. https://www. fgcu.edu/cob/reri/idp/

Forbes, D. (2005). Managerial determinants of decision speed in new ventures. Strategic Management Journal, 26(4), 355-366.

Fornell, C., \& Larcker, D. F. (1981). Evaluating structural equation models with unobservable variables and measurement error. Journal of Marketing Research, 18(1), 39-50.

Fourne, S. P. L., Jansen, J. J. P., \& Mom, T. J. M. (2014). Strategic agility in MNEs: Managing tensions to capture opportunities across emerging and established markets. California Management Review, 56(3), 1337.

Freeman, J., Carroll, G. R., \& Hannan, M. T. (1983). The liability of newness: Age dependence in organizational death rates. American Sociological Review, 48(5), 692710 .

Garcia-Morales, V. J., Llorens-Montes, F. J., \& Verdu-Jo- 
ver. (2007). Influence of personal mastery on organizational performance through organizational learning and innovation in large firms and SMEs. Technovation, 27(9), 547-568.

Gopalakrishnan, S., \& Bierly, P. E. (2006). The impact of firm size and age on knowledge strategies during product development: A study of the drug delivery industry. IEEE Transactions on Engineering Management, 53(1), 3-16.

Grantham, C. E., Ware, J. P., \& Williamson, C. (2007). Corporate agility: A revolutionary new model for competing in flat world. AMACOM.

Groves, R. M. (2006). Nonresponse rates and nonresponse bias in household surveys. Public Opinion Quarterly, 70(5), 646-675.

Gunasekaran, A. (2001). Agile manufacturing: The $21^{\text {st }}$ century competitive strategy. Elsevier.

Gunter, F. R. (2012). A simple model of entrepreneurship for principles of economics courses. The Journal of Economic Education, 43(4), 386-396.

Hamalainen, T., Kosonen, M., \& Doz, Y. L. (2012). Strategic agility in public management. (Working paper 2012/30/ST). INSEAD.

Hannan, M. T., \& Freeman, J. (1984). Structural inertia and organizational change. American Sociological Review, 49(2), 149-164.

Hayes, A. F. (2018). Introduction to mediation, moderation, and conditional process analysis: A regression-based approach. Guilford Press.

Ivory, S. B., \& Brooks, S. B. (2018). Managing corporate sustainability with a paradoxical lens: Lessons from strategic agility. Journal of Business Ethics, 148(2), 347-361.

Jacoby, C. H., Jr., \& Shaw, R. L. (2016). Strategic agility theory and practice. Joint Forces Quarterly, 81, 34-42.

Junni, P., Sarala, R. M., Tarba, S. Y., \& Weber, Y. (2015). The role of strategic agility in acquisitions. British Journal of Management, 26(4), 596-616.

Kale, E., Aknar, A., \& Basar, O. (2019). Absorptive capacity and firm performance: The mediating role of strategic agility. International Journal of Hospitality Management, 78, 276-283.

Khoshnood, N. T., \& Nematizadeh, S. (2017). Strategic agility and its impact on the competitive capabilities in iranian private banks. International Journal of Business and Management, 12(2), 220-229.

Kirzner, I. M. (1997). Entrepreneurial discovery and the competitive market process: An Austrian approach. Journal of Economic Literature, 35(1), 60-85.

Kumkale, I. (2016). Organization's tool for creating competitive advantage: Strategic agility. Balkan and Near
Eastern Journal of Social Sciences, 2(03), 118-124.

Kwon, S. J., Ryu, D., \& Park, E. (2018). The influence of entrepreneurs' strategic agility and dynamic capability on the opportunity pursuit process of new ventures: Evidence from South Korea. Academy of Strategic Management Journal, 17(1), 1-17.

Lewis, M. W., Andriopoulos, C., \& Smith, W. K. (2014). Paradoxical leadership to enable strategic agility. California Management Review, 56(3), 58-76.

Long, C. (2000). You don't have a strategic plan? - Good! Consulting to Management, 11(1), 35-42.

Lu, Y., \& Ramamurthy, K. (2011). Understanding the link between information technology capability and organizational agility: An empirical examination. MIS Quarterly, 35(4), 931-954.

Lumpkin, G. T., \& Dess, G. G. (1996). Clarifying the entrepreneurial orientation construct and linking it to performance. Academy of Management Review, 21(1), 135-172.

Nadler, D. A., \& Tushman, M. L. (1989). A model for diagnosing organizational behavior: Applying a congruence perspective. In D. A. Nadler, M. L. Tushman, \& C. O'Reilly (Eds.). The management of organizations: Strategies, tactics, analyses (pp. 91-106). Harper \& Row.

Nagel, R. N. (1992). $21^{\text {st }}$ century manufacturing enterprise strategy report (AMEF N0001-92). Arlington, VA: Office of Naval Research.

Nagel, R. N., \& Dove, R. (1991). $21^{\text {st }}$ Century Manufacturing Enterprise Strategy: An industry-led view. Diane Publishing.

Netemeyer, R. G., Bearden, W. O., \& Sharma, S. (2003). Scaling Procedures: Issues and Applications. SAGE.

Nunally, J. C. (1978). Psychometric theory. McGraw Hill.

Ofoegbu, O. E., \& Akanbi, P. A. (2012). The influence of strategic agility on the perceived performance of manufacturing firms in Nigeria. International Business \& Economics Research Journal, 11(2), 153-160.

Ojha, D. (2008). Impact of strategic agility on competitive capabilities and financial performance (Accession/ Order No. 3339487) [Doctoral dissertation, Clemson University]. ProQuest Dissertations and Theses.

Penrose, E. T. (1959). The theory of the growth of the firm. John Wiley \& Sons.

Powell, T. C. (1992). Organizational alignment as competitive advantage. Strategic Management Journal, 13(2), 119-134.

Quiros, I. (2009). Organizational alignment: A model to explain the relationships between organizational relevant variables. International Journal of Organizational Analysis, 17(4), 285-305. 
Roth, A. V. (1996). Achieving strategic agility through economies of knowledge. Strategy \& Leadership, 24(2), 30-36.

Rumelt, R. P. (1991). How much does industry matter? Strategic Management Journal, 12(3), 167-185.

Sambamurthy, V., Bharadwaj, A., \& Grover, V. (2003). Shaping agility through digital options: Reconceptualizing the role of information technology in contemporary firms. MIS Quarterly, 27(2), 237-263.

Semler, S. W. (1997). Systematic agreement: A theory of organizational alignment. Human Resource Development Quarterly, 8(1), 23-40.

Shin, H., Lee, J., Kim, D., \& Rhim, H. (2015). Strategic agility of Korean small and medium enterprises and its influence on operational and firm performance. International Journal of Production Economics, 168, 181196.

Space Coast Economic Development Commission. (2019). Interactive data center. https://spacecoastedc.org/data-downloads/dashboard/

Space Coast Economic Development Commission. (2018). Florida's space coast named 'turnaround of the year' by SpaceNews. https://secure.spacecoastedc.org/np/ clients/spacecoastedc/news.jsp?news $=122$

Sullivan, L. E., Johnson, R. B., Mercado, C. C., \& Terry, K. J. (2009). The SAGE glossary of the social and behavioral sciences (1st ed.). SAGE.

Teece, D. J. (2009). Dynamic capabilities and strategic management. Oxford University Press.

Teece, D. J., Peteraf, M., \& Leih, S. (2016). Dynamic capabilities and organizational agility: Risk, uncertainty, and strategy in the innovation economy. California management review, 58(4), 13-35.

Teece, D., Pisano, G., \& Shuen, A. (1997). Dynamic capabilities and strategic management. Strategic Management Journal, 18(7), 509-533.

U.S. Small Business Administration (2012). Survival rates and firm age. https://www.sba.gov/advocacy/ small-business-facts-and-infographics

Vecchiato, R. (2015). Creating value through foresight: First mover advantages and strategic agility. Technological Forecasting \& Social Change, 101, 25-36.

Weber, Y., \& Tarba, S. Y. (2014). Strategic agility: A state of the art. California Management Review, 56(3), 5-12.

Winter, S. G. (2003). Understanding dynamic capabilities. Strategic Management Journal, 24(10), 991-995.

Yusuf, Y. Y., Gunasekaran, A., Adeleye, E. O., \& Sivayoganathan, K. (2004). Agile supply chain capabilities: Determinants of competitive objectives. European Journal of Operational Research, 159(2), 379-392. 


\section{Appendix A - Latent Variable Scales}

\section{Strategic Sensitivity}

1. My organization anticipates future products and services needed by customers.

2. My organization uses experimenting (e.g., prototypes, pilots, in-market tests) to probe the future.

3. My organization considers a wide range of potential products and services by viewing our business in abstract terms.

\section{Leadership Unity}

1. The leaders of my organization engage in open dialogue and welcome differences of opinion.

2. The leaders of my organization operate as an integrated, interdependent, value-creating team.

3. The leaders of my organization are aligned around a common interest through a compelling mission, aspirational vision, shared values, and emotion.

4. The leaders of my organization are caring and demonstrate empathy and compassion for others.

\section{Resource Fluidity}

1. My organization's underlying business systems and processes are modular and easily changed.

2. My organization uses multiple business models for different market segments or products.

3. My organization adopts new ways of doing business from other companies.

\section{Environmental Turbulence}

1. How complex is your company's external environment?

2. How rapidly do challenges evolve in the external environment?

3. How novel is each challenge in the external environment?

4. How frequently does the external environment shift between being stable and unstable?

\section{Organizational Alignment}

1. There is a rational flowdown of goals within my organizational structure.

2. The cultural values of my organization are consistent with our strategic goals.

3. The cultural norms for behavior in my organization are consistent with our tactics.

4. There is good fit between the demands of the external environment and our strategic goals and tactics. 